\title{
PERLINDUNGAN HUKUM BAGI PEMEGANG HAK MEREK DAGANG IKEA ATAS PENGHAPUSAN MEREK DAGANG
}

\author{
Rahmadia Maudy Putri Karina ${ }^{2 *}$, Rinitami Njatrijani² \\ 1Program Studi Magister IImu Hukum, Fakultas Hukum, Universitas Diponegoro \\ 2Fakultas Hukum, Universitas Diponegoro \\ rahmadiakarina@gmail.com
}

\begin{abstract}
Trademark dispute cases that are talking in Indonesia is a case involving PT Inter IKEA System BV Sweden VS PT Ratania Khatulistiwa. The emergence of IKEA trademark between PT Ratania Khatulistiwa and PT Inter IKEA System BV Sweden occurs because of an Application Request for Registration of Trademark "IKEA" for grade 20 and grade 21. The existence of the dispute caused PT Ratania Khatulistiwa filed abolition IKEA brand top good classes 20 and 21 owned by PT Inter IKEA System BV Sweden because the brand is not used and is not visible in the market within a period of three years in a row. The purpose of this research was to know when PT Inter IKEA Systems BV Sweden losthe brand and to find out the legal protection for the trademark holder's IKEA. The method used in this research is normative juridical law, using the literature as the main data. Results from this study is IKEA brand owned by PT Inter IKEA System BV Sweden otherwise have been removed after the Supreme Court issued Decision Number 264/K/Pdt.Sus-HKI/2015. PT Ratania Khatulistiwa has obtained legal protection from legal actions mark registration IKEA they register at the Directorate General of $\mathrm{HKI}$, and based on the law of PT Ratania Khatulistiwa can be third parties are allowed to apply for the elimination of brand IKEA that is not used by PT Inter IKEA System BV Sweden, although PT Ratania Khatulistiwa is not the first registrant on the IKEA brand.
\end{abstract}

\section{Keywords: Legal Protection; Rights Holders; Deletion; Brand; IKEA.}

\begin{abstract}
ABSTRAK
Kasus sengketa merek yang ramai dibicarakan di Indonesia adalah kasus antara PT Inter IKEA System BV Swedia VS PT Ratania Khatulistiwa. Adanya sengketa tersebut menyebabkan PT Ratania Khatulistiwa mengajukan gugatan penghapusan merek IKEA atas produk barang kelas 20 dan 21 yang dimiliki oleh PT Inter IKEA System BV Swedia dikarenakan merek tersebut tidak digunakan dan tidak terlihat dipasaran dalam kurun waktu 3 tahun berturut-turut. Tujuan penelitian ini adalah untuk mengetahui kapan PT Inter IKEA System BV Swedia kehilangan hak atas mereknya dan untuk mengetahui perlindungan hukum bagi pemegang hak merek dagang IKEA. Metode pendekatan yang digunakan dalam penelitian hukum ini adalah yuridis normatif, yaitu menggunakan bahan kepustakaan sebagai data utama. Hasil dari penelitian ini adalah merek IKEA milik PT Inter IKEA System BV Swedia dinyatakan telah dihapus setelah Mahkamah Agung RI mengeluarkan Putusan Nomor 264/K/PDT.Sus-HKI/2015. PT Ratania Khatulistiwa memperoleh perlindungan hukum dari perbuatan hukum pendaftaran merek IKEA yang didaftarkannya di Direktorat Jenderal HKI, serta berdasarkan hukum PT Ratania Khatulistiwa dapat menjadi pihak ketiga yang diizinkan untuk mengajukan permohonan penghapusan merek IKEA yang tidak digunakan oleh PT Inter IKEA System BV Swedia, walaupun PT Ratania Khatulistiwa bukan merupakan pendaftar pertama atas merek IKEA tersebut.
\end{abstract}

Kata kunci: Perlindungan Hukum; Pemegang Hak; Penghapusan; Merek; IKEA.

\footnotetext{
${ }^{*}$ Corresponding Author
} 


\section{A. PENDAHULUAN}

Pada era globalisasi seperti sekarang ini, bisnis semakin berkembang. Kita perlu mempelajari bisnis karena dunia bisnis sangat mempengaruhi kehidupan seseorang khususnya para pelaku usaha. Diperlukan juga kemampuan para pelaku usaha untuk membaca pasar, yaitu terkait pemilihan kualitas benda atau jasa yang ditawarkan dan profesionalitas dalam memuaskan pembeli atau pelanggannya khususnya mengenai pemilihan merek dagang yang akan menjadi simbol dari produk yang dihasilkan oleh pelaku usaha.

Keberadaan Hak Kekayaan Intelektual (selanjutnya disingkat $\mathrm{HKI}$ ) senantiasa mengikuti dinamika perkembangan masyarakat itu sendiri. Begitu pula halnya dengan masyarakat Indonesia yang mau tidak mau bersinggungan dan terlibat langsung dengan masalah HKI. Permasalahan mengenai $\mathrm{HKI}$ akan menyentuh berbagai aspek seperti aspek teknologi, industri, sosial, budaya, dan berbagai aspek lainnya (Erlina, 2013).

Kemajuan dunia perdagangan, baik dalam skala nasional maupun internasional, membuat para pelaku bisnis semakin memperhatikan objek perdagangan mereka. Apalagi di era globalisasi ketika arus barang berputar sangat cepat dan luas. Merek menunjukkan asal dan kualitas produk dan jasa yang diperdagangkan (Ramadhiani \& Budiningsih, 2017).

Merek adalah salah satu bagian dari wujud karya intelektual memiliki peranan penting bagi kelancaran dan peningkatan perdagangan barang atau jasa dalam kegiatan perdagangan dan investasi yang terjadi pada perkembangan globalisasi sekarang ini. Demikian pentingnya peranan merek ini, maka terhadapnya dilekatkan perlindungan hukum, yakni sebagai objek terhadapnya terkait hakhak perseorangan atau badan hukum (Sutedi, 2009).

Peran merek dalam dunia pemasaran sangat penting, karena publik sering mengkaitkan suatu kualitas atau reputasi barang dan jasa dengan merek tertentu. Merek juga harus memiliki daya pembeda yang cukup, artinya memiliki kekuatan untuk membedakan barang atau jasa produk suatu perusahaan lainnya (Khoironi, 2013).

Hak Merek merupakan salah satu bentuk perlindungan Hak Kekayaan Intelektual (HKI) dimana hak eksklusif akan diberikan kepada pemilik pendaftaran atas suatu merek untuk menggunakan mereknya tersebut dalam perdagangan barang atau jasa untuk mana ia terdaftar. Jika suatu merek terdaftar untuk jenis pakaian jadi, misalnya, maka hak eksklusif si pemilik merek adalah sebagai satusatunya orang yang berhak menggunakan merek tersebut sebagai merek pakaian jadi, tapi tidak untuk jenis barang atau jasa yang lain (Setiadharma, 2016).

Pendaftaran atas merek merupakan suatu keharusan bagi pemilik merek, akan tetapi hak atas merek hanya akan diberikan oleh Direktorat Merek jika permintaan pendaftaran merek oleh pemohon merek dilakukan dengan itikad baik. Unsur itikad baik dalam suatu permintaan pendaftaran merek merupakan unsur yang penting. Pemohon yang beritikad baik adalah pemohon yang mendaftarkan 195 
mereknya secara jujur dan layak tanpa ada niat apapun untuk membonceng, meniru, atau menjiplak ketenaran merek pihak lain demi kepentingan usahanya yang berakibat kerugian pada pihak lain itu atau menimbulkan kondisi persaingan curang, mengecoh atau menyesatkan konsumen (Mardianto, 2010).

Pelaksanaan perjanjian lisensi merek tidak dapat dilepaskan dari sengketa yang diakibatkan karena para pihak tidak memenuhi hak dan kewajibannya sebagaimana mestinya. Jika salah satu pihak melanggar hal-hal yang telah disepakati dalam perjanjian, maka akan timbul sngketa diantara mereka. Jika ada sengketa, maka para pihak akan membawa sengketa tersebut ke pengadilan atau diselesaikan melalui penyelesaian sengketa sesuai dengan kesepakatan yang terjadi diantara mereka (Sujatmiko, 2011).

Di Indonesia sering dijumpai kasus mengenai klaim atas merek. Kasus sengketa merek yang sedang ramai dibicarakan di Indonesia adalah kasus yang melibatkan PT Inter IKEA System BV Swedia VS PT Ratania Khatulistiwa.

PT Inter IKEA System BV Swedia (IKEA Swedia) merupakan sebuah perusahaan yang didirikan oleh Ingvar Kampard pada tahun 1943 pada saat ia berusia 17 tahun yang sekarang sudah menjadi salah satu orang terkaya di dunia. (IKEA, 2016)

Nama IKEA sendiri merupakan singkatan dari nama pendirinya, adapun rinciannya sebagai berikut :
-I : Ingvar, yang merupakan nama depannya;

-K : Kampard, merupakan nama belakangnya;

-E : Elmtaryd, tempat kelahirannya;

-A : Agunnaryd, yaitu adalah nama desannya.

Pengucapan IKEA adalah /l'ke.a/ seperti cara membaca Bahasa Indonesia umumnya, namun pengucapan lainnya yang banyak digunakan adalah laI'ki: / pengucapannya seperti kata Bahasa Inggris, idea.

Pada tahun 2013 PT Ratania Khatulistiwa yang merupakan perusahaan rotan asal Surabaya menggugat IKEA Swedia ke Pengadilan Niaga Jakarta Pusat berdasarkan hasil survey Berlian Group Indonesia (BGI). BGI merupakan lembaga yang netral dan independen serta berpengalaman dalam melakukan market survey di Indonesia. BGI telah melakukan market survey di lima kota besar di Indonesia, yang mewakili seluruh Indonesia, yakni Medan, Jakarta, Bandung, Surabaya dan Denpasar, dalam kurun waktu November sampai dengan Desember 2013, dengan melakukan market survey secara eksklusif melalui wawancara terhadap 140 (seratus empat puluh) toko/responden. Bahwa hasil market survey ini dilakukan oleh pewawancara BGI tersebut dapat disimpulkan bahwa produk-produk dengan merek IKEA untuk kelas 20 dan 21 tidak pernah dijual dan/ atau tidak pernah diedarkan di toko-toko furniture di seluruh wilayah Republik Indonesia. IKEA Swedia belum memiliki atau belum membuka tokonya di Indonesia untuk menjual atau mengedarkan produk-produk dengan merek IKEA di wilayah Indonesia. 
Jurnal Pembangunan Hukum Indonesia

Volume 1, Nomor 2, Tahun 2019
Program Studi Magister Ilmu Hukum Fakultas Hukum Universitas Diponegoro
Mengetahui merek yang telah dianggurkan oleh pemiliknya ini maka PT Ratania Khatulistiwa mendaftarkan merek IKEA miliknya pada tanggal 20 Desember 2013. Menurut PT Ratania Khatulistiwa, IKEA Swedia telah mendaftarkan mereknya tertanggal 9 Oktober 2006 dan 27 Oktober 2010. Maka dari itu IKEA Swedia dianggap telah menganggurkan mereknya selama tiga tahun berturut-turut. Dasar hukum yang relevan adalah pasal 61 ayat (1) huruf a Undang-Undang No. 15 Tahun 2001 tentang Merek yang saat telah diganti dengan Undang-Undang No. 20 Tahun 2016 tentang Merek dan Indikasi Geografis Pasal 74 ayat (1), yang menyebutkan bahwa Penghapusan pendaftaran Merek atas prakarsa Direktorat Jenderal dapat dilakukan jika merek tidak digunakan selama 3 tahun berturut-turut dalam perdagangan barang dan/atau jasa sejak tanggal pendaftaran atau pemakaian terakhir kecual apabila ada alasan yang dapat diterima oleh Direktorat Jenderal.

Pada tanggal 17 September 2014, Pengadilan Niaga Jakarta Pusat mengabulkan gugatan PT Ratania Khatulistiwa. Dalam putusan tersebut menyatakan merek IKEA dimiliki oleh PT Ratania Khatulistiwa dan memerintahkan merek IKEA Swedia harus dicabut. Setelah diputusnya putusan tersebut, IKEA Swedia mengajukan kasasi di Mahkamah Agung. Atas kasasi dari IKEA Swedia, Mahkamah Agung memutuskan menolak permohonan kasasi pemohon dalam hal ini IKEA Swedia dalam putusannya Nomor 264/K/PDT.SUSHKI/2015.
Sebelumnya ada beberapa penelitian yang mengangkat tema mengenai penghapusan, pembatalan merek dagang dan perlindungan hokum merek terkenal diantaranya berfokus pada keputusan hakim dalam menilai penggunaan merek dagang, para hakim hanya melihat inkonsistensi writing, gaya atau font atau warna, tapi tidak memperhatikan pertimbangan tujuan dan niat dari pihak yang menyatakan sengketa (Mardianto, 2010). Kemudian terdapat penelitian mengenai pembatalan merek dagang yang berfokus terhadap itikad baik mengenai pengaturan tata cara pendaftaran akan suatu merek yang harus ditolak dan tidak dapat didaftarkan serta perlindungan hukum terhadap pemilik merek terdaftar, tetapi masih sering didapati permasalahan dalam pemeriksaan merek dan hal yang sering menjadi permasalahan adalah mengenai persamaan pada pokoknya atau keseluruhan dan mengenai merek terkenal (Far-Far, Sigito, \& Alam, 2014). Penelitian lain mengenai kelemahan Undang-Undang Merek dalam hal pendaftaran merek di Indonesia yaitu tidak adanya persyaratan filosofi merek dan menimbulkan adanya multitafsir pemahaman mengenai merek terkenal dan persamaan pada pokoknya atau keseluruhannya (Perdana, 2017).

Selain penelitian-penelitian tersebut ada beberapa jurnal internasional yang mengangkat tema mengenai perlindungan hukum merek terkenal yaitu berfokus pada perlindungan merek terkenal di India yang masih lemah dalam melindungi pemilik merek yang jujur (Choudhary, 2010). Kemudian terdapat yang berfokus pada dua perspektif teoritis yang 197 
menjelaskan mengenai perlindungan merek dagang asing terkenal di suatu Negara. Merek yang telah memiliki reputasi berhak mendapatkan perlindungan di tiap Negara dimana barang dagangan milik merek terkenal tersebut dipasarkan (Grinvald, 2010).

Pada penelitian dalam artikel ini menekankan pada perlindungan hukum pemegang hak merek dagang IKEA ditinjau dari Putusan Mahkamah Agung Nomor 264 / K / PDT.SUS - HKI / 2015 dan perlindungannya terhadap pemilik merek yang beritikad baik. Selain itu penulis juga akan menganalisis sengketa yang terjadi antara PT Inter IKEA System BV Swedia dan PT Ratania Khatulistiwa berdasarkan Undang undang Nomor 15 Tahun 2001 tentang Merek dan dikomparasikan dengan Undang-Undang Merek terbaru yaitu Undang Undang No 20 Tahun 2016 tentang Merek dan Indikasi Geografis. Titik fokus tersebut yang membedakan penelitian yang akan dilaksanakan oleh penulis dengan penelitian-penelitian sebelumnya.

Berdasarkan latar belakang tersebut, maka dapat dirumuskan rumusan permasalahan sebagai berikut : 1. Sejak kapan PT Inter IKEA System BV Swedia kehilangan hak atas mereknya menurut Undang-Undang Nomor 15 Tahun 2001 tentang Merek ?; 2.Bagaimana perlindungan hukum bagi pemegang hak merek dagang IKEA ditinjau dari Putusan Mahkamah Agung Nomor 264/K/PDT.SUSHKI/2015?

\section{B. METODE PENELITIAN}

Metode pendekatan yang digunakan dalam artikel ini adalah pendekatan yuridis normatif, yaitu suatu pendekatan yang mengacu pada hukum dan peraturan perundang-undangan yang berlaku. Dalam penelitian ini digunakan spesifikasi penelitian secara deskriptif analitis. Deskriptif, yaitu penelitian yang bertujuan melukiskan tentang suatu hal di daerah tertentu dan pada saat tertentu.

Penelitian ini menggunakan sumber data kepustakaan. Jenis datanya adalah data sekunder yaitu data yang diperoleh melalui bahan pustaka dengan cara mengumpulkan dari berbagai sumber bacaan yang berhubungan dengan masalah yang diteliti. Analisis yang digunakan dalam penelitian ini menggunakan analisis kualitatif, yaitu menganalisis data yang berupa bahan-bahan hukum dan bahanbahan pustaka. Analisis dilakukan dengan penafsiran terhadap data hasil penelitian. Hasil analisis disajikan secara sederhana dan sistematis.

\section{HASIL DAN PEMBAHASAN}

1. PT. Inter IKEA System BV Swedia Kehilangan Hak Atas Mereknya Menurut Undang-Undang Nomor 15 Tahun 2001 tentang Merek

Menurut Pasal 61 ayat (2) butir a UndangUndang No. 15 Tahun 2001 tentang Merek yang telah diganti dengan Undang-Undang No. 20 Tahun 2016 tentang Merek dan Indikasi Geografis Pasal 74 ayat (1), penghapusan pendaftaran Merek atas prakarsa Direktorat Jenderal dapat dilakukan jika merek tidak digunakan selama 3 tahun berturut-turut 198 
dalam perdagangan barang dan/atau jasa sejak tanggal pendaftaran atau pemakaian terakhir kecuali apabila ada alasan yang dapat diterima oleh Direktorat Jenderal.

Berdasarkan Pasal 61 sampai dengan Pasal 63 Undang-Undang Nomor 15 Tahun 2001 tentang Merek terdapat tiga cara penghapusan merek terdaftar, yaitu :

1. Penghapusan atas prakarsa Direktorat Jenderal $\mathrm{HKl}$;

2. Penghapusan atas permohonan pemilik merek, dan

3. Penghapusan karena gugatan pihak ketiga dalam bentuk gugatan kepada Pengadilan.

Penghapusan pendaftaran Merek dari Daftar

Umum Merek atas prakarsa Direktorat Jenderal dapat dilakukan jika:

1. Merek tidak digunakan selama 3 (tiga) tahun berturut-turut dalam perdagangan barang dan/atau jasa sejak tanggal pendaftaran atau pemakaian terakhir, kecuali apabila ada alasan yang dapat diterima oleh Direktorat Jenderal; atau

2. Merek digunakan untuk jenis barang dan/atau jasa yang tidak sesuai dengan jenis barang dan/atau jasa yang dimohonkan pendaftaran, termasuk pemakaian merek yang tidak sesuai dengan merek yang didaftar.

Permohonan penghapusan pendaftaran merek oleh pemilik merek atau Kuasanya, baik sebagian atau seluruh jenis barang dan/atau jasa, diajukan kepada Direktorat Jenderal.
Penghapusan pendaftaran merek dapat pula diajukan oleh pihak ketiga dalam bentuk gugatan ke Pengadilan Niaga berdasarkan Pasal 63 UndangUndang Nomor 15 Tahun 2001 tentang Merek dengan alasan-alasan sebagaimana dimaksud dalam Pasal 61 ayat (2) huruf a dan huruf b. Penghapusan Pendaftaran Merek berdasarkan gugatan pihak ketiga akan dilakukan oleh Direktorat Jenderal HKI apabila putusan pengadilan tentang hal tersebut telah diterima dan mempunyai kekuatan hukum tetap. Apabila gugatan penghapusan pendaftaran merek diterima dan telah mempunyai kekuatan hukum yang tetap maka Direktorat Jenderal HKI akan melaksanakan penghapusan merek yang bersangkutan dari Daftar Umum Merek dan mengumumkannya dalam Berita Resmi Merek.

Bentuk perlawanan yang kedua adalah gugatan penghapusan, dimana penggugat meminta agar suatu merek terdaftar dihapus dari Daftar Umum Merek dengan alasan karena pemilik merek tidak menggunakan merek tersebut selama tiga tahun berturut-turut.

Pada kasus sengketa merek dagang IKEA ini, penghapusan disebabkan karena adanya gugatan pihak ketiga kepada Pengadilan. PT Ratania Khatulistiwa menggugat PT Inter IKEA System BV Swedia kepada Pengadilan karena menganggap bahwa PT Inter IKEA System BV Swedia telah menganggurkan mereknya selama 3 (tiga) tahun berturut-turut. Pengadilan Niaga mengabulkan gugatan penghapusan tersebut. PT Inter IKEA System BV Swedia kemudian memohon kasasi ke 199 
Mahkamah Agung namun pada tanggal 12 Mei 2015 Mahkamah Agung Republik Indonesia memutuskan untuk menolak permohonan kasasi dari PT Inter IKEA System BV Swedia yang sekaligus bermakna menguatkan putusan Pengadilan Niaga sebelumnya.

Setelah dibacakannya putusan Mahkamah Agung Nomor 264/K/PDT.Sus-HKI/2015 PT Inter IKEA System BV Swedia harus merelakan merekmerek terdaftar IDM000093006 dan IDM000277901 miliknya dihapuskan dari Daftar Umum Merek Indonesia.

\section{Perlindungan Hukum Bagi Pemegang Hak Merek Dagang IKEA Ditinjau Dari Putusan Mahkamah Agung Nomor 264/K/PDT.Sus- HKI/2015}

a. Analisis Pertimbangan Hakim Mahkamah Agung

Pada tanggal 17 September 2014, Hakim Pengadilan Niaga Jakarta Pusat telah memberikan putusan terhadap kasus PT Ratania Khatulistiwa VS PT Inter IKEA System BV Swedia. Dalam putusan Nomor 99 / PDT.Sus - Merek / 2013 / PN.Niaga.Jkt.Pst Hakim mengabulkan permohonan penggugat dan menghapuskan merek "IKEA" milik PT Inter IKEA System BV Swedia. Kemudian pada tanggal 6 Oktober 2014 PT Inter IKEA System BV Swedia mengajukan Permohonan Kasasi dengan Akta Permohonan Kasasi Nomor 42Kas/Pdt.SusHaKI/2014/PN.Niaga.Jkt.Pst. Jo. Nomor 99/PDT.SusMerek/2013/PN.Niaga.Jkt.Pst.
Pada Putusan Mahkamah Agung No. 264 K/Pdt.Sus-HKI/2015 antara PT Ratania Khatulistiwa dengan PT Inter IKEA System BV Swedia, hakim memutuskan untuk menolak kasasi dari Pemohon Kasasi.

Mahkamah Agung menyatakan bahwa J udex Facti oleh Pengadilan Niaga pada Pengadilan Negeri Jakarta Pusat sudah tepat dan benar serta tidak salah menerapkan hukum. Dengan alasan bahwa merek yang tidak diguakan oleh pemiliknya selama 3 tahun berturut-turut dapat dihapus dari Daftar Umum Merek.

Pada pertimbangan Judex Facti, termohon merupakan pihak ketiga yang berkepentingan untuk mengajukan gugatan penghapusan terhadap Pendaftaran Merek "IKEA". Termohon Kasasi telah melakukan kegiatan usaha industri membuat dan memproduksi berbagai macam produk-produk perabot rumah yang terbuat dari kayu atau rotan, sehingga perlu mendapatkan perlindungan atas merek dari Negara dalam hal ini Kementerian Hukum dan Hak Asasi Manusia R.I cq Direktorat Jenderal Hak Kekayaan Intelektual.

Di dalam gugatannya, Termohon Kasasi mendalilkan hal-hal sebagai berikut:

"... Hal ini tidak sesuai lagi dengan amanat Undang-Undang Nomor 15 Tahun 2001 tentang Merek dan sudah sepantasnya perlindungan hukum terhadap merek "IKEA" milik Tergugat berakhir dan dihapus, Penggugat, sebaliknya sebagai perusahaan nasional di bidang furniture adalah pihak yang hendak menggunakan merek "IKEA" tersebut agar dapat membawa manfaat bagi perekonomian nasional Indonesia. Dengan 
Jurnal Pembangunan Hukum Indonesia

Volume 1, Nomor 2, Tahun 2019
Program Studi Magister Ilmu Hukum Fakultas Hukum Universitas Diponegoro demikian, Penggugat adalah pihak ketiga yang berkepentingan untuk mengajukan gugatan dalam perkara ini"

Terkait dengan maksud Termohon Kasasi tersebut, Pemohon Kasasi berpendapat bahwa pengajuan permintaan pendaftaran Merek "IKEA" oleh Termohon Kasasi adalah atas dasar itikad tidak baik, dilandasi maksud meniru dan membonceng keterkenalan Merek "IKEA" milik Pemohon Kasasi. Di Indonesia, untuk mendaftarkan Merek harus berdasarkan itikad baik. Pemohon yang beritikad baik adalah Pemohon yang mendaftarkan mereknya secara layak dan jujur tanpa ada niat apapun untuk membonceng, meniru atau menjiplak ketenaran merek pihak lain demi kepentingan usahanya yang berakibat kerugian pada pihak lain itu atau menimbulkan kondisi persaingan curang, mengecoh, atau menyesatkan konsumen. Dalam kasus ini, Termohon Kasasi menggunakan Merek "IKEA" dengan maksud membawa manfaat bagi perekonomian nasional Indonesia.

Dalam gugatannya, Termohon Kasasi mendalilkan hal-hal sebagai berikut:

"...Penggugat, sebaliknya sebagai perusahaan nasional di bidang furniture adalah pihak yang hendak menggunakan merek "IKEA" tersebut agar dapat membawa manfaat bagi perekonomian nasional Indonesia. Dengan demikian, Penggugat adalah pihak ketiga yang berkepentingan untuk mengajukan gugatan dalam perkara ini".

Berdasarkan dalil tersebut, jelas bahwa Termohon Kasasi hanya berencana untuk menggunakan Merek "IKEA" dan hingga saat ini
Termohon Kasasi belum mengambil upaya komersial apapun yang terkait penggunaan Merek "IKEA". Dalam pertimbangan hakim, apabila semua orang maupun badan hukum dapat mengajukan suatu gugatan penghapusan hanya bermodalkan permohonan pendaftaran merek dan rencana penggunaan suatu merek, sangat mudah bagi setiap orang ataupun badan hukum tersebut untuk mengkualifikasi dirinya sendiri selaku pihak yang berkepentingan, hal yang mana tidak akan menciptakan suatu kepastian hukum.

Berdasarkan hasil market survey ternyata membuktikan bahwa produk-produk merek "IKEA" yang didaftarkan Tergugat untuk kelas 20 dan kelas 21, telah terbukti tidak pernah dijual dan/atau tidak pernah diedarkan oleh Tergugat, dalam dunia perdagangan barang dan jasa di Indonesia, sejak tanggal pendaftarannya hingga tanggal gugatan ini didaftarkan, hal tersebut jelas membuktikan bahwa Tergugat tidak menggunakan merek "IKEA" selama tiga tahun berturut-turut sejak tanggal pendaftarannya.

Hal ini sesuai dengan Pasal 61 ayat (2) huruf (a) Undang-Undang No. 15 Tahun 2001 tentang Merek yang telah diganti dengan Undang-Undang No. 20 Tahun 2016 tentang Merek dan Indikasi Geografis Pasal 74 ayat (1) yang menyatakan bahwa:

"....Penghapusan pendaftaran Merek atas prakarsa Direktorat Jenderal dapat dilakukan jika:

a. Merek tidak digunakan selama 3 (tiga) tahun berturut-turut dalam perdagangan 
barang dan/atau jasa sejak tanggal pendaftaran atau pemakaian terakhir, kecuali apabila ada alasan yang dapat diterima oleh Direktorat Jenderal".

\section{Penjelasan Pasal 61 ayat (2) huruf} Undang-Undang No. 15 Tahun 2001 dinyatakan, yang dimaksud "Pemakaian Terakhir" adalah peggunaan merek tersebut pada produksi barang atau jasa yang diperdagangkan. Saat pemakaian terakhir tersebut dihitung dari tanggal terakhir pemakaian sekalipun setelah itu barang yang bersangkutan masih beredar di masyarakat.

Terkait dengan hal tersebut, maka Judex Facti telah mencabut hak merek dari Pemohon Kasasi yang telah terbukti digunakan dengan itikad baik pada kegiatan perdagangan yang nyata.

Pemohon Kasasi telah mengajukan bukti-bukti kegiatan proudksi berbagai jenis produk di kelas 20 dan kelas 21 yaitu berupa konfirmasi produksi dari produsen lokal di Indonesia. Hal tersebut memang dapat dijadikan sebagai bukti bahwa Merek IKEA dengan kelas 20 dan kelas 21 memang pernah di produksi di Indonesia. Namun ternyata setelah dilakukan survey oleh Penggugat melalui market survey Berlian Grup Indonesia (BGI) ternyata produk IKEA tersebut tidak dijual di Indonesia dan ternyata Chou Per Lian tidak pernah didengar sebagai saksi di depan persidangan sehingga pernyataan atau bukti yang diserahkan tersebut tidak mempunyai kekuatan pembuktian dan harus dikesampingkan.

Pemohon Kasasi menambahkan bukti berupa dokumentasi gambar yang membuktikan keberadaan toko resmi Pemohon Kasasi di Indonesia yaitu tepatnya di Jalan Alam Sutera, Tangerang.

Menurut pertimbangan Hakim, bukti tentang gambar toko-toko tersebut tidak dapat menunjukkan bahwa Tergugat telah atau sedang memasarkan produk-produknya. Toko tersebut memang ada, tetapi belum bisa membuktikan barang pada Kelas 20 dan Kelas 21 dijual dan diedarkan di pasaran.

Hal lain selain bukti-bukti dokumentasi yang diajukan, Pemohon Kasasi juga menilai survey yang diajukan oleh Termohon Kasasi tidak akurat dan cenderung menyesatkan. Dalam dalilnya, Penggugat menyatakan bahwa Tergugat hingga saat ini tidak memiliki satupun toko di wilayah Republik Indonesia untuk Kelas barang/jasa 16, 35, 20, 11, 24, 42 dan 21 ataupun Tergugat tidak memiliki pabrik, distributor resmi, agen resmi, dealer resmi, pengecer resmi, maupun perwakilan resmi untuk memperdagangkan barang-barang Merek "IKEA", ataupun Tergugat tidak melakukan aktivitas produksi, perdagangan dan penyediaann untuk barang-barang dengan Merek. Pemohon Kasasi menilai dalil tersebut mengada-ada dan hanya didasarkan pada asumsi-asumsi yang dihasilkan dari sebuah suvey yang sangat meragukan. Termohon Kasasi tidak melakukan survey di seluruh kota yang seharusnya layak untuk disurvey untuk membuktikan tidak digunakannya Merek IKEA milik Pemohon Kasasi. Termohon Kasasi melakukan survey di Jakarta, sementara toko IKEA milik Pemohon Kasasi berada di Jalan Alam Sutera, Tangerang. Hasil survey tersebut dinilai oleh Pemohon Kasasi adalah manipulasi dan tidak 
dilakukan berdasarkan metode yang benar dan komperhensif. Apabila Penggugat jeli dalam menyusun Gugatannya dan memang telah mengambil langkah strategis yang diperlukan untuk mengajukan gugatan penghapusan Merek, seharusnya Penggugat dapat melihat dengan jelas keberadaan Toko Resmi IKEA yang berada di Alam Sutera Tangerang.

Menurut Hakim katidakakuratan hasil survey tersebut tidak mengherankan karena dalam database Putusan Mahkamah Agung, Berlian Group Indonesia selaku lembaga survey yang ditunjuk oleh Termohon Kasasi, tidak pernah menjadi rujukan bagi para Hakim Mahkamah Agung ataupun Pengadilan Niaga dalam memutus perkara penghapusan merek. Maka tidak mengherankan apabila Termohon Kasasi tidak mampu menemukan penjualan dan pendistribusian berbagai produk-produk "IKEA" milik Pemohon Kasasi untuk jenis barang dalam Kelas 20 dan Kelas 21 yang dilakukan di Indonesia, bahkan melalui penelusuran online yang dapat dilakukan oleh siapapun. Tidak mengherankan juga apabila lembaga survey yang ditunjuk oleh Termohon Kasasi, Berlian Group Indonesia, juga tidak mampu mengetahui adanya penggunaan Pendaftaran Merek "IKEA" oleh Pemohon Kasasi secara mendalam, baik terkait proses produksi yang dilakukan oleh Pemohon Kasasi terhadap berbagai jenis barang di Kelas 20 dan Kelas 21 dengan Pendaftaran Merek "IKEA" di Indonesia, maupun kegiatan perdagangan dengan menggunakan Pendaftaran Merek "IKEA" Pemohon
Kasasi yang dilakukan oleh Pemohon Kasasi dengan berbagai pihak di Indonesia.

Dalam dalilnya dikemukakan bahwa Pemohon Kasasi adalah perusahaan yang bergerak, antara lain di bidang produksi peralatan dan perlengkapan rumah tangga dan keperluan kantor yang berasal dari Negara Swedia, yang melakukan penjualan secara langsung kepada para konsumen atau para pemakai secara ritel/ eceran dalam skala internasional dengan menggunakan Merek "IKEA" dan kombinasi-kombinasinya.

Sebagai bentuk tanggung jawab sosial, Pemohon Kasasi juga mengemban tanggung jawab sosial perusahaan dengan mendukung dan bekerjasama dengan Organisasi Kesehatan Dunia (WHO), badan organisasi Perserikatan BangsaBangsa yaitu Organisasi Dunia untuk anak-anak (UNICEF) dan organisasi non pemerintah berskala internasional yang berasal dari Negara Inggris, Save The Children, yang bergerak dalam misi mencegah anak-anak dipekerjakan sebagai buruh. Selain itu Pemohon Kasasi bekerjasama dengan organisasi non pemerintah berskala internasional yang bergerak di bidang lingkungan hidup, WWF (World Wide Foundation) yang bergerak dalam misi mencegah penebangan dan penjualan hasil hutan secara liar dan illegal.

Pada pertimbangannya, Mahkamah Agung berpendapat bahwa keberatan-keberatan yang diajukan oleh Pemohon Kasasi tidak dapat dibenarkan. Mahkamah Agung menghubungkan memori kasasi dengan pertimbangan judex facti 203 
dalam hal ini Pengadilan Niaga pada Pengadilan Negeri Jakarta Pusat sudah tepat dan benar serta tidak salah menerapkan hukum.

Mahkamah Agung menilai judex facti telah sesuai dengan ketentuan Pasal 61 ayat (2) huruf a Undang-Undang Nomor 15 Tahun 2001 tentang Merek yang telah diganti dengan Undang-Undang No. 20 Tahun 2016 tentang Merek dan Indikasi Geografis Pasal 74 ayat (1), maka merek yang tidak digunakan oleh pemiliknya selama 3 (tiga) tahun berturut-turut dapat dihapus dari Daftar Umum Merek, hal tersebut telah terbukti dalam pemeriksaan bahwa merek dagang IKEA untuk kelas barang/jasa Kelas 20 dan Kelas 21 dengan Nomor Pendaftaran IDM000092006 dan Nomor Pendaftaran IDM000277901 telah tidak digunakan oleh Tergugat selama 3 (tiga) tahun berturut-turut sejak merek dagang tersebut terdaftar, karena itu putusan J udex Facti dalam perkara tersebut sudah tepat sehingga layak untuk dipertahankan.

Namun demikian, Hakim Agung anggota I Gusti Agung Sumanatha menyatakan beda pendapat (dissenting opinion). Menurut I Gusti Agung Sumanatha, keberatan-keberatan kasasi dapat dibenarkan dan Judex Facti telah salah dalam menerapkan hukum dengan pertimbangan bahwa Pemohon Kasasi/Tergugat dapat membuktikan dalilnya bahwa Merek "IKEA" Tergugat telah terdaftar secara sah dan merupakan merek terkenal yang harus dilindungi dan tidak terdapat alasanalasan untuk dihapus, secara kasat mata toko-toko milik Tergugat yang menjual produk-produknya tersebar dan di Indonesia toko resmi IKEA yang cukup besar berada di Jalan Alam Sutera Tangerang sehingga menurut I Gusti Agung Sumanatha Pasal 61 ayat (2) huruf a Undang-Undang No. 15 Tahun 2001 tentang Merek tidak dapat diterapkan.

Oleh karena terjadi perbedaan pendapat dalam Majelis Hakim dan telah diusahakan musyawarah tetapi tidak tercapai mufakat, maka Majelis Hakim mengambil putusan dengan suara terbanyak.

\section{b. Amar Putusan Mahkamah Agung Nomor 264 K/PDT.Sus-HKI/2015}

Terhadap Permohonan Kasasi yang diajukan oleh PT Inter IKEA System BV Swedia pada tanggal 6 Oktober 2014, Mahkamah Agung telah memberi putusan Nomor 264 K/PDT.Sus-HKI/2015, pada tanggal 12 Mei 2015 yang amarnya sebagai berikut:

Menimbang, bahwa berdasarkan pertimbangan tersebut di atas, ternyata bahwa Putusan Pengadilan Niaga pada Pengadilan Negeri Jakarta Pusat dalam perkara ini tidak bertentangan dengan hukum dan/atau undang-undang, sehingga permohonan kasasi yang diajukan oleh Pemohon Kasasi INTER IKEA SYSTEM B.V tersebut harus ditolak.

Menimbang, bahwa oleh karena permohonan kasasi dari Pemohon Kasasi ditolak, Pemohon Kasasi harus dihukum untuk membayar biaya perkara dalam tingkat kasasi ini; Memperhatikan, Undang-Undang Nomor 15 Tahun 2001 tentang Merek, Undang-Undang Nomor 48 Tahun 2009 204 
tentang Kekuasaan Kehakiman, Undang-Undang Nomor 14 Tahun 1985 tentang Mahkamah Agung sebagaimana yang telah diubah dengan UndangUndang Nomor 5 Tahun 2004 dan perubahan kedua dengan Undang-Undang Nomor 3 Tahun 2009, serta peraturan perundang-undangan lain yang bersangkutan yang menyatakan bahwa :

\section{ME N G A D I L I}

Menolak permohonan kasasi dari Pemohon Kasasi INTER IKEA SYSTEM B.V tersebut.

Menghukum Pemohon Kasasi untuk membayar biaya perkara dalam tingkat kasasi sebesar Rp5.000.000,00 (lima juta rupiah).

Diputuskan dalam rapat permusyawaratan Majelis Hakim pada Mahkamah Agung pada hari Selasa tanggal 12 Mei 2015 yang terdiri: Syamsul Ma'arif, S.H., LL.M., Ph.D., sebagai Hakim Agung yang ditetapkan oleh Ketua Mahkamah Agung sebagai Ketua Majelis, Dr. H. Abdurrahman, S.H., M.H., dan I Gusti Agung Sumanatha, S.H., M.H., Hakim-Hakim Agung, masing-masing sebagai Anggota, putusan tersebut diucapkan dalam siding terbuka untuk umum pada hari itu juga oleh Ketua dengan dihadiri oleh Anggota-Anggota tersebut dan Nawangsari, S.H., M.H.m Panitera Pengganti tanpa dihadiri oleh para Pihak.

\section{c. Bentuk Perlindungan Hukum Bagi Pemegang Hak Merek Dagang IKEA Di Tinjau Dari Putusan Mahkamah Agung Nomor 264 K/PDT.Sus-HKI/2015}

Pengertian perlindungan hukum adalah suatu perlindungan yang diberikan terhadap subyek hukum dalam bentuk perangkat hukum baik yang bersifat preventif maupun yang bersifat represif, baik yang tertulis maupun tidak tertulis, dengan kata lain perlindungan hukum sebagai suatu gambaran dari fungsi hukum, yaitu konsep dimana hukum dapat memberikan suatu keadilan, ketertiban, kepastian, kemanfaatan dan kedamaian.

Pemberian perlindungan hak atas merek, hanya diberikan kepada pemilik merek yang mereknya sudah terdaftar saja. Perlindungan merek diberikan manakala terjadi suatu pelanggaran merek yang dilakukan oleh pihak yang tidak mempunyai hak terhadap suatu merek. Dalam dunia perdagangan merek mempunyai peranan yang penting, karena dengan merek yang terkenal maka akan dapat mempengaruhi keberhasilan suatu usaha terutama dalam hal pemasaran. Dalam dunia perdagangan sering terjadi pelanggaran terhadap merek terkenal. Pelanggaran terjadi karena ada pihak yang tidak mempunyai hak menggunakan merek terdaftar untuk kepentingannya (Mirfa, 2016).

Undang-Undang Nomor 15 Tahun 2001 tentang Merek saat ini mengatur dalam UndangUndang Nomor 20 Tahun 2016 tentang Merek dan Indikasi Geografis, sistem pendaftaran merek menggunakan sistem konstitutif atau sistem first to file principal dimana suatu merek akan mendapatkan perlindungan hukum jika telah didaftarkan, jadi pendaftaran merek merupakan suatu keharusan.

Di Indonesia, dalam menjalankan dan memberikan perlindungan hukum terdapat dua sarana perlindungan hukum, yaitu Sarana 
Perlindungan Hukum Preventif, dimana subyek hukum diberikan kesempatan untuk mengajukan keberatan atau pendapatnya sebelum suatu keputusan pemerintah mendapat bentuk yang definitif. Selain itu terdapat Sarana Perlindungan Hukum Represif yang bertujuan untuk menyelesaikan sengketa.

Pada sengketa merek IKEA antara PT Ratania Khatulistiwa dengan PT Inter IKEA System BV Swedia ini pada akhirnya dimenangkan oleh PT Ratania Khatulistiwa. Dalam putusannya, Mahkamah Agung menolak Permohonan Kasasi dari PT Inter IKEA System BV Swedia dan menyatakan bahwa judex facti sudah tepat sehingga layak untuk dipertahankan.

PT Ratania Khatulistiwa mengetahui bahwa PT Inter IKEA System BV sejak tanggal pendaftaran merek-merek untuk kelas barang/jasa kelas 20 dan Kelas 21 PT Inter IKEA System BV tidak pernah menjual dan/atau tidak pernah mengedarkan barangbarang dengan merek "IKEA" di wilayah Republik Indonesia di toko-toko furniture diseluruh wilayah Republik Indonesia hingga saat gugatan didaftarkan. PT Inter IKEA System BV juga tidak memiliki store (toko/gerai) untuk menjual atau mengedarkan produk-produk dengan merek "IKEA". Hal ini membuktikan bahwa merek "IKEA" Nomor Pendaftaran IDM000277901 tanggal 27 Oktober 2010 dan Merek "IKEA" dengan Nomor Pendaftaran IDM000092006 tanggal 09 Oktober 2006 tersebut tidak dugunakan selama 3 (tiga) tahun berturut-turut dalam perdagangan barang di Indonesia sejak tanggal pendaftaran.

Fakta tersebut diketahui oleh PT Ratania Khatulistiwa melalui market survey yang dilaksanakan oleh Berlian Group Indonesia (BGI). BGI telah melakukan market survey di 5 (lima) kota besar di Indonesia, yang mewakili seluruh wilayah Indonesia, yakni Medan, Jakarta, Bandung, Surabaya dan Denpasar, dalam kurun waktu November sampai dengan Desember 2013, dengan melakukan market survey secara eksklusif melalui wawancara terhadap 140 (seratus empat puluh) toko/responden. Bahwa market survey ini dilakukan oleh pewancara $\mathrm{BGI}$ yang telah terlatih dan berpengalaman, wawancara dilakukan secara netral tanpa menyebutkan tujuan dari market survey tersebut. Bahwa berdasarkan hasil market survey tersebut dapat disimpulkan atau ditemukan fakta bahwa produk-produk dengan merek "IKEA" atas nama PT Inter IKEA System BV untuk kelas 20 dan 21 tidak pernah dijual dan/atau tidak pernah diedarkan di toko-toko furniture di seluruh wilayah Republik Indonesia maupun di toko milik PT Inter IKEA System BV, karena terbukti sampai dengan tanggal pendaftaran gugatan ini, PT Inter IKEA System BV selaku Tergugat belum memiliki atau belum membuka tokonya di Indonesia untuk menjual atau mengedarkan produk-produk dengan merek "IKEA" di wilayah Indonesia. Dari hasil market survey tersebut membuktikan bahwa produk-produk merek "IKEA" yang didaftarkan Tergugat untuk kelas 20 dan kelas 21, tidak pernah dijual dan/atau tidak pernah 206 
Jurnal Pembangunan Hukum Indonesia

Volume 1, Nomor 2, Tahun 2019
Program Studi Magister Ilmu Hukum Fakultas Hukum Universitas Diponegoro diedarkan oleh Tergugat, dalam dunia perdagangan barang dan jasa di Indonesia, sejak tanggal pendaftarannya hingga tanggal gugatan ini didaftarkan.

Hal tersebut membuktikan bahwa Tergugat telah tidak menggunakan merek "IKEA" selama 3 (tiga) tahun berturut-turut sejak tanggal pendaftarannya, dalam hal ini:

- Tergugat tidak menggunakan merek "IKEA" Nomor Pendaftaran IDM000277901 kelas 20 selama 3 (tiga) tahun berturut-turut di Wilayah Republik Indonesia sejak tanggal 27 Oktober 2010;

- Tergugat tidak menggunakan merek "IKEA" Nomor Pendaftaran IDM00092006 kelas 21 selama 3 (tiga) tahun berturut-turut di wilayah Republik Indonesia, sejak tanggal 09 Oktober 2006.

Dalam Pasal 61 ayat (2) huruf a dan b Undang-Undang Nomor 15 Tahun 2001 tentang Merek yang saat ini diatur dalam Pasal 74 ayat (1) Undang-Undang No. 20 Tahun 2016 tentang Merek dan Indikasi Geografis, tidak digunakannya suatu merek selama 3 (tiga) tahun berturut-turut sejak tanggal pendaftaran dan juga adanya pemakaian merek yang tidak sesuai dengan merek yang didaftarkan, merupakan alasan-alasan penghapusan pendaftaran merek. Pasal 61 ayat (2) huruf a dan $b$ Undang-Undang No. 15 Tahun 2001 tentang Merek menjelaskan sebagai berikut:

(1).

(2). Penghapusan pendaftaran merek atau prakarsa Direktorat Jenderal dapat dilakukan jika: a. Merek tidak digunakan selama 3 (tiga) tahun berturut-turut dalam perdagangan barang dan/atau jasa sejak tanggal pendaftaran atau pemakaian terakhir, kecuali apabila ada alasan yang dapat diterima oleh Direktorat Jenderal ; atau

b. Merek digunakan untuk jenis barang dan/atau jasa yang tidak sesuai dengan jenis barang atau jasa yang dimohonkan pendaftaran, termasuk pemakaian Merek yang tidak sesuai dengan Merek yang didaftar.

Selanjutnya di dalam Penjelasan Pasal 61 ayat (2) huruf a UndangUndang Merek, dinyatakan juga: "Yang dimaksud dengan "pemakaian terakhir" adalah penggunaan merek tersebut pada produksi barang atau jasa yang diperdagangkan. Saat pemakaian terakhir tersebut dihitung dari tanggal terakhir pemakaian sekalipun setelah itu barang yang bersangkutan masih beredar di masyarakat".

Prinsip dasar pertama yang harus dipahami adalah bahwa hak eksklusif atas merek di Indonesia -yang diatur berdasarkan Undang-Undang Nomor 15 Tahun 2001- hanya diberikan pada merek yang telah terdaftar di Direktorat Jenderal Kekayaan Intelektual, Kementerian Hukum dan Hak Asasi Manusia Republik Indonesia (DJKI). Pendaftaran merek tersebut menganut prinsip first-to-file, dimana hak akan diberikan kepada pendaftar pertama. Prinsip ini berlaku di hampir semua Negara, terkecuali di beberapa Negara dengan sistem hukum anglo-saxon seperti Inggris dan Amerika Serikat, dimana selain first-to-file juga diakui perlindungan berdasarkan firstto-use atau pemakaian pertama kali (Setiadharma, 2016)

Selain first-to-file, sistem perlindungan merek di dunia -termasuk Indonesia- menganut pula prinsip teritorialitas, yaitu bahwa hak eksklusif merek hanya 
berlaku di wilayah Negara dimana merek tersebut didaftar. Dengan demikian, perusahaan-perusahaan yang aktivitas bisnisnya berlangsung lintas Negara mutlak perlu melakukan pendaftaran atas merekmereknya di Negara-negara dimana aktivitas bisnisnya tersebut berada.

PT Inter IKEA System BV merupakan perusahaan asing di bidang furniture dan akan mengembangkan usahanya di Indonesia, maka dari itu PT Inter IKEA System BV mendaftarkan mereknya di Indonesia pada tahun 2010 untuk Kelas 20 dan tahun 2006 untuk Kelas 21. Namun berdasarkan survey, PT Inter IKEA terbukti tidak menggunakan merek "IKEA" 3 (tiga) tahun berturut-turut, sehingga dapat dinilai PT Inter IKEA System BV sebagai perusahaan asing tidak memanfaatkan perlindungan merek yang telah diberikan Negara Republik Indonesia kepadanya atau sudah menyia-nyiakan merek yang telah didaftarkannya tersebut. Hal ini tidak sesuai lagi dengan amanat Undang-Undang Nomor 15 Tahun 2001 tentang Merek dan sudah sepantasnya perlindungan hukum terhadap merek "IKEA" milik PT Inter IKEA System BV berakhir dan dihapus, sebaliknya sebagai perusahaan nasional dibidang furniture, PT Ratania Khatulistiwa adalah pihak yang hendak menggunakan merek "ikea" tersebut agar dapat membawa manfaat bagi perekonomian nasional Indonesia.

Berdasarkan Pasal 61 dan 63 Undang-Undang Merek 2001 terdapat tiga cara penghapusan merek terdaftar, yaitu : Penghapusan atas prakarsa Dirjen HKI, penghapusan atas permohonan pemilik merek, dan penghapusan karena gugatan pihak ketiga dalam bentuk gugatan kepada Pengadilan. Dalam Undang-Undang Merek yang baru yaitu UndangUndang No. 20 Tahun 2016, penghapusan merek terdaftar diatur dalam Pasal 72 dan Pasal 74. Dalam Undang-Undang Merek yang baru tidak banyak perubahan mengenai pengaturan penghapusan merek terdaftar, hanya sedikit yang berubah yaitu dalam Undang-Undang No. 15 Tahun 2001 tentang Merek, penghapusan merek dapat dilakukan atas prakarsa Dirjen HKI, namun dalam Undang-Undang Merek yang baru yaitu Undang-Undang No. 20 Tahun 2016 tentang Merek dan Indikasi Geografis, penghapusan merek terdaftar dapat dilakukan atas prakarsa Menteri.

Untuk penghapusan pendaftaran merek atas prakarsa sendiri, Pasal 62 ayat (1) Undang-Undang No. 15 Tahun 2001 tentang Merek yang telah diganti dengan Undang-Undang No. 20 Tahun 2016 tentang Merek dan Indikasi Geografis Pasal 72 menyebutkan bahwa suatu merek terdaftar dapat diajukan penghapusannya atas permintaan pemilik merek yang bersangkutan. Permohonan penghapusan pendaftaran merek oleh pemilik merek atau kuasanya, baik sebagian atau seluruh jenis barang dan/atau jasa, diajukan kepada Dirjen HKI. Permintaan penghapusan merek oleh pemilik merek dapat diajukan untuk sebagian atau seluruh jenis barang atau jasa yang termasuk dalam satu kelas, pertimbangan pemilik merek dalam hal ini, biasanya karena mereknya dianggap sudah tidak menguntungkan lagi. 
Permintaan penghapusan pendaftaran merek terdaftar oleh pemilik merek harus diajukan secara tertulis dalam Bahasa Indonesia kepada Dirjen HKI dengan menyebutkan merek terdaftar dan nomor pendaftaran merek yang bersangkutan.

Terhadap putusan Pengadilan niaga yang dimaksud hanyalah dapat diajukan pada tingkat kasasi. Panitera pengadilan yang bersangkutan segera menyampaikan isi putusan Pengadilan tersbut kepada Direktorat Jendral HKI yang dimana hanya akan melaksanakan penghapusan merek yang bersangkutan dari Daftar Umum Merek apabila putusan badan peradilannya telah diterima dan berkekuatan hukum tetap.

Peghapusan hanya dapat dilakukan apabila terdapat bukti yang cukup bahwa merek yang bersangkutan :

Tidak dipakai (nonuse) berturut-turut selama 3 tahun atau lebih dalam perdagangan barang atau jasa terhitug sejak tanggal pendaftaran atau pemakaian terakhir. Namun demikian apabila ada alasan yang kuat mengapa merek itu tidak digunakan, Direktorat Jenderal dapat mempertimbangkan untuk tidak dilakukan penghapusan atas merek tersebut.

Dipakai untuk jenis barang atau jasa yang tidak sesuai dengan jenis barang atau jasa yang dimohonkan pendaftarannya atau tidak sesuai dengan merek yang di daftar.

Berdasarkan ketentuan Pasal 63 UndangUndang Nomor 15 Tahun 2001 tentang Merek, Penggugat sebagai pihak ketiga dapat mengajukan gugatan penghapusan pendaftaran merek "IKEA" atas nama Tergugat Nomor Pendaftaran IDM000277901 Kelas 20 dan Nomor Pendaftaran IDM000092006 Kelas 21, berdasarkan alasan sebagaimana dimaksud dalam Pasal 61 ayat (2) huruf $a$ dan b Undang-Undang Nomor 15 Tahun 2001 tentang Merek dalam bentuk gugatan kepada Pengadilan Niaga. Pasal 63 Undang-Undang Nomor 15 Tahun 2001 tentang Merek berbunyi:

"Penghapusan pendaftaran Merek berdasarkan alasan sebagaimana dimaksud dalam Pasal 61 ayat (2) huruf $a$ dan huruf $b$ dapat pula diajukan oleh pihak ketiga dalam bentuk gugatan kepada Pengadilan Niaga".

Pasal 61 ayat 2 huruf (a) jo. Pasal 63 UndangUndang No. 15 Tahun 2001 tentang Merek memberikan hak pada pihak ketiga dalam mengajukan gugatan penghapusan pendaftaran merek kepada Pengadilan Niaga atas merek yang tidak digunakan selama 3 (tiga) tahun berturut-turut dalam perdagangan barang dan/atau jasa. Dalam hal ini PT Ratania Khatulistiwa berhak untuk mengajukan gugatan penghapusan pendaftaran merek.

Artikel ini menganalisis bahwa judex facti dalam putusan tersebut sudahlah tepat dan harus dijalankan. Pasalnya, PT Inter IKEA System BV yang merupakan perusahaan asing yang mengembangkan usahanya di Indonesia telah memiliki Sertifikat Pendaftaran Merek "IKEA", tetapi PT Inter IKEA System BV tidak memanfaatkan hak yang diberikan oleh Pemerintah Republik Indonesia. PT Inter IKEA System BV telah menganggurkan mereknya selama lebih dari 3 (tiga) tahun. Maka dari 
Jurnal Pembangunan Hukum Indonesia

Volume 1, Nomor 2, Tahun 2019
Program Studi Magister Ilmu Hukum Fakultas Hukum Universitas Diponegoro itu, Merek "IKEA" milik PT Inter IKEA System BV untuk kelas 20 dan kelas 21 memang benar harus dihapuskan.

\section{SIMPULAN}

Timbulnya sengketa merek IKEA antara PT Ratania Khatulistiwa dan PT Inter IKEA System BV Swedia terjadi karena adanya Permohonan Permintaan Pendaftaran Merek "IKEA" untuk kelas 20 dan kelas 21 yang telah diterima pada tanggal 20 Desember 2013 dengan nomor agenda D002013061337 untuk kelas 20 dan D002013061336 untuk kelas 21 yang dilakukan oleh PT Ratania Khatulistiwa. Pada saat itu merek IKEA sudah ada dan dimiliki oleh PT Inter IKEA System BV Swedia yang telah terdaftar dalam Daftar Umum Merek Direktorat Jenderal HAKI pada tanggal 27 Oktober 2010 untuk kelas 20 dan tanggal 9 Oktober 2006 untuk kelas 21. Adanya sengketa tersebut menyebabkan PT Ratania Khatulistiwa mengajukan gugatan penghapusan merek IKEA atas produk barang kelas 20 dan 21 yang dimiliki oleh PT Inter IKEA System BV Swedia dikarenakan merek tersebut tidak digunakan dan tidak terlihat dipasaran dalam kurun waktu 3 tahun berturur-turut sehingga bedasarkan Pasal 61 ayat (2) Undang-Undang Nomor 15 tahun 2001 tentang Merek yang telah diganti dengan Undang-Undang No. 20 Tahun 2016 tentang Merek dan Indikasi Geografis Pasal 74 ayat (1), apabila Merek tidak digunakan selama 3 (tiga) tahun berturut-turut dalam perdagangan barang dan/atau jasa sejak tanggal pendaftaran atau pemakaian terakhir maka Merek dapat dihapuskan atas prakarsa Direktorat Jenderal HAKI. Merek IKEA milik PT Inter IKEA System BV Swedia dinyatakan telah dihapus setelah Mahkamah Agung Republik Indonesia mengeluarkan Putusan Nomor 264/K/PDT.Sus-HKI/2015.

Perlindungan hukum bagi pemegang hak merek dagang IKEA ditinjau dari Putusan Mahkamah Agung Nomor 264/K/PDT.SUS-HKI/2015 dapat dilihat dari prinsip dasar pertama dari ketentuan Undang-Undang Nomor 15 Tahun 2001 tentang Merek yang saat ini telah diganti dengan UndangUndang Nomor 20 Tahun 2016 tentang Merek dan Indikasi Geografis yaitu hak ekslusif dari sebuah merek hanya diberikan pada merek yang telah terdaftar di Direktorat Jenderal Kekayaan Intelektual, Kementerian Hukum dan Hak Asasi Manusia Republik Indonesia. Pendaftaran merek tersebut menganut prinsip first-to-file, dimana hak akan diberikan kepada pendaftar pertama. Apabila terdapat merek yang telah terdaftar namun tidak secara nyata digunakan oleh pemegang hak merek, maka dapat diajukan penghapusan atas merek tersebut sebagaimana diatur dalam Pasal 61 ayat (2) Undang-Undang Nomor 15 tahun 2001 tentang Merek yang telah diganti dengan Undang-Undang No. 20 Tahun 2016 tentang Merek dan Indikasi Geografis Pasal 74 ayat (1), dengan ketentuan merek tersebut tidak digunakan selama 3 tahun berturut-turut. PT Ratania Khatulistiwa memperoleh perlindungan hukum dari perbuatan hukum pendaftaran merek IKEA yang didaftarkannya di 210 
Direktorat Jenderal Kekayaan Intelektual DAFTAR PUSTAKA

Kementerian Hukum dan Hak Asasi Manusia A. BUKU

Republik Indonesia, serta berdasarkan hukum PT

Sutedi, A. (2009). Hak Kekayaan Intelektual. Jakarta:

Ratania Khatulistiwa dapat menjadi pihak ketiga yang Sinar Grafika.

diizinkan untuk mengajukan permohonan penghapusan merek IKEA yang tidak digunakan oleh PT Inter IKEA System BV Swedia, walaupun PT Ratania Khatulistiwa bukan merupakan pendaftar pertama atas merek IKEA tersebut.

Berdasarkan uraian diatas maka penulis memberikan masukan dan saran kepada beberapa pihak antara lain:

Bagi Pelaku usaha yang memerlukan merek sebagai produk dagang yang dijual belikan, sebaiknya segera melakukan pendaftaran atas merek yang telah dimiliki sehingga merek tersebut memiliki kekuatan hukum dan hak ekslusif.

Bagi Pemerintah khususnya Direktorat Jenderal Kekayaan Intelektual sangat diperlukan adanya sosialisasi akan pentingnya pendaftaran merek dalam persaingan pengusaha-pengusaha di Indonesia. Sampai saat ini kesadaran masyarakat khususnya para pengusaha menengah kebawah masih belum meyakini pentingnya pendaftaran merek atas suatu produk yang dimilikinya. Akibatnya banyak usaha-usaha kecil yang berasal dari usaha kegiatan rumah tangga ternyata produknya ditiru dan diedarkan oleh pihak lain yang memanfaatkan kesuksesan pemilik merek pertama tersebut.

\section{B. JURNAL}

Choudhary, Vivek K. (2010). Protection of Well Known Trademarks and Weakening of Honest Concurrent User Defense. Journal of Intellectual Property Rights, Vol. 15, July 2010, pp. 293-301.

Erlina, B. (2013). Analisis Penghapusan Merek Terdaftar Oleh Direktorat Merek (Studi pada Direktorat Jenderal Hak Kekayaan Intelektual Kementrian Hukum dan Hak Asasi Manusia Republik Indonesia). Jurnal Pranata Hukum, Vol 8, (No. 1), p.34.

Far-Far, Charles Yeremia., Sigito, Sentot., \& Alam, Zairul. (2014). Tinjauan Yuridis Pembatalan Merek Dagang Terdaftar Terkait Prinsip Itikad Baik (Good Faith) Dalam Sistem Pendaftaran Merek. Jurnal Hukum Universitas Brawijaya, Vol. 4, (No.1), p.4.

Grinvald, Leah C. (2010). A Tale of Two Theories of Well-Known Marks. Vanderbilt Journal of Entertainment and Technology Law, Vol. 13, (No. 1), p.3.

Khoironi, Iffan A. (2013). Implementasi Pendaftaran Merek Sebagai Bentuk Perlindungan Hukum Pada Home Industry Eggroll. Unnes Law J ournal, Vol.2, (No.2), p.130. 
Jurnal Pembangunan Hukum Indonesia

Volume 1, Nomor 2, Tahun 2019
Program Studi Magister Ilmu Hukum Fakultas Hukum Universitas Diponegoro

Mardianto, A. (2010). Penghapusan Pendaftaran

Merek Berdasarkan Gugatan Pihak Ketiga.

J urnal Dinamika Hukum, Vol. 10, (No. 1), p.44.

Mirfa, E. (2016). Perlindungan Hukum Terhadap

Merek Terdaftar. Jurnal Hukum Samudra

Keadilan, Vol. 11, (No.1), p.66.

Perdana, K. (2017). Kelemahan Undang-Undang Merek Dalam Hal Pendaftaran Merek (Studi Atas Putusan Sengketa Merek Pierre Cardin).

J urnal Privat Law, Vol. 5, (No.2), p.91.

Ramadhiani, Nur Febry., \& Budiningsih, Catharina

Ria. (2017). Analisis Hukum Penghapusan

Merek IKEA. J urnal Syiar Hukum UNISBA, Vol

15, (No. 2), p.140.

Sujatmiko, A. (2011). Prinsip Penegakan Hukum

Pelanggaran Perjanjian Lisensi Merek

Terkenal. Jurnal Masalah-Masalah Hukum, Vol.40, (No.3), p.271.

\section{PUTUSAN}

Mahkamah Agung, Putusan No. 264/K/Pdt.Sus-

HKI/2015

\section{SUMBER ONLINE}

Setiadharma, P. (2016). Sedikit Kisah Tentang Hapusnya Merek IKEA. Retrieved from http://www.hki.co.id/artikel

IKEA. (2016). Tentang IKEA. Retrivied from m.ikea.com/ms/in_ID/this-is-IKEA/about-theIKEA-group/index.html 